\section{WHAT DO YOU THINK OF APPRENTICESHIPS?}

Two short surveys have been released to gather the dental industry's thoughts on apprenticeships and what areas need improvement.

The Government has announced that apprenticeships need to be reformed so that they all provide substantial and sustained training that equips apprentices with transferable skills and full competency in an occupation. To achieve this, new scheme Trailblazers was developed. This initiative puts employers at the forefront of apprenticeship reform, and allows them to collaborate on designing apprenticeships within their sector.

Apprenticeships for the Dental Health Sector are currently in development, with plans to improve the current dental nurse apprenticeship and to create apprenticeships for practice managers and dental technicians.

Take part in the surveys at www.surveymonkey. com/s/TrailblazersPM and www.surveymonkey.com/s/ TBdentalhealthtech.

To read more about Trailblazers visit https:// www.gov.uk/government/uploads/system/uploads/ attachment_data/file/287276/bis-14-p194-future-ofapprenticeships-in-england-guidance-for-trailblazersrevised-version-2.pdf.

\section{CAUSE FOR APPLAUSE}

Specialist dental accountant and University of Bristol lecturer John Carter has won the support of Great British Bake Off judge Mary Berry who is supporting the fundraising appeal for a Positron scanner for Bath's Royal United Hospital. Mary is helping the Bath Cancer Unit Support Group, of which John is Honorary Chief Executive, achieve its target of €1.2 million.

Throughout National Smile Month 2014 (May-June), dental hygienist Christina Chatfield is walking 500 miles for charity from Scotland to Brighton, all in aid of mouth cancer action, and is looking for volunteers to join her along the way. For more information see www.500miles4smiles.org.

Selina Dicker plans to conquer Everest this summer to change the lives of over 300 children who, like her, were born with cleft lip and cleft palate. The lack of normal muscle in Selina's lip makes it more difficult to exhale, making the treacherous climb at high altitudes even more challenging. Selina is supporting international children's medical charity Operation Smile.

A team of solicitors from Goodman Grant lawyers is undertaking the Coast to Coast challenge on 23 May to raise money for Bridge2Aid. Members of the Liverpool and Leeds offices will embark on a three-day cycle ride taking them 180 miles across the width of the country, from St Bees in Cumbria to Robin Hood's Bay in the North Yorkshire Moors National Park.

\section{DENTAL ART}

\section{DENTISTRY THROUGH ART. PART 5}

The following images and descriptions are taken from dental students Rebecca Little and Lorna Hopps' fourth year elective project.

\section{Mirth and anguish}

Figure 1. This piece of art is from a series called Human Passions Delineated. A dentist holds a hot coal towards his petrified patient who recoils back in fear, putting great tension on the string, resulting in the extraction of the tooth. Disturbingly, the dentist appears to be enjoying himself.

This poem describes the scene:

'Now strings put fast on tooth that aches,

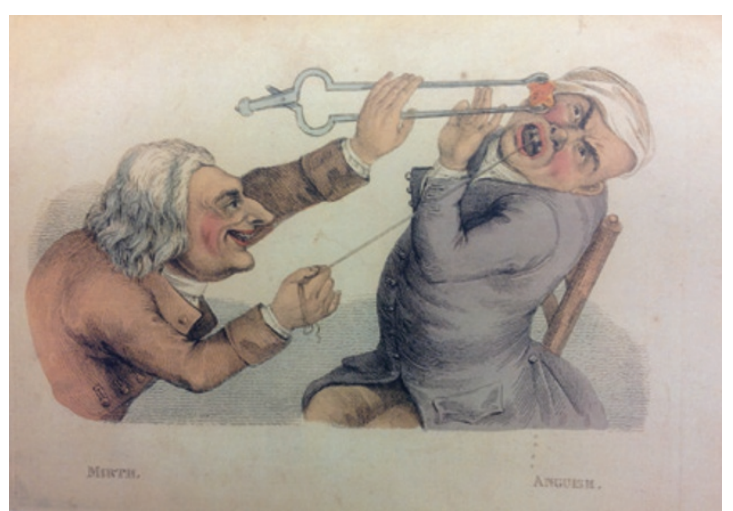

Fig. 1 Mirth and anguish. John Collier (1708-1786). 1773 Print. Copyright Trustees of the British Museum. Reproduced with permission from the British Museum, London

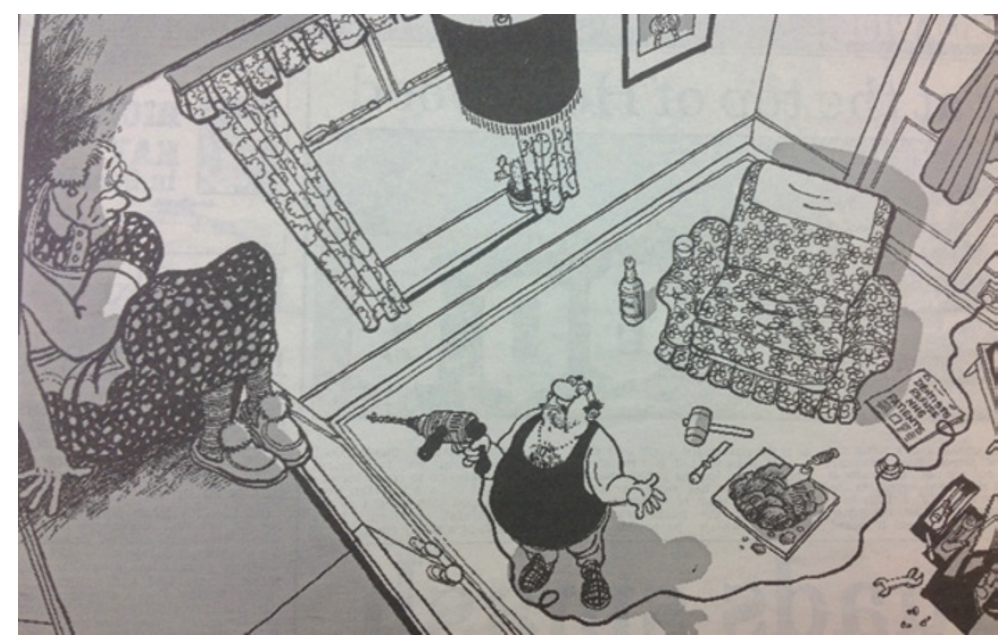

Fig. 2 'Ah c'mon love, you know we can't afford to go private'. Stanley McMurtry (1936 - present). Featured in the Daily Mail 7 July 1992. Reproduced with permission from Stanley McMurtry and Solo Syndication, the Daily Mail

Which round his hand he wraps, A glowing coal I'th tongs he takes, And to his nose he claps. The sight and smell of fire drove back,

The patient's head in fright, Who drew his own tooth in a crack, And proved the doctor right. ${ }^{1-3}$

'Ah c'mon love, you know we can't afford to go private' Figure 2. A comical newspaper clipping depicts a man chasing his wife with a large hand drill, exclaiming that they cannot afford the dentist. The scene is viewed from a high and angled perspective, looking down into the room to see what the woman is afraid of. The drawing shows a working class family, highlighted by their dress and décor. The fact that he possesses a drill and plastering tools suggests he is a tradesman. A paper on the floor reads 'Dentists refuse NHS patients' making this a very topical image at the time. ${ }^{2}$

1. Trevers J, Orskey M. Open wide! A series of eighteenth and nineteenth century caricatures on dentistry. Wychwood Books, 2009.

2. Discussions with Dr Maureen Park and Professor David McGowan

3. Curtis E. Hand to mouth: essays on the art of dentistry. p 34. Quintessence, 2002. 